\title{
Effect of Cactus Plants on Magnetic Fields Bruited by Computer Screens
}

\section{Bilgisayar Ekranlarının Yaydığı Manyetik Alanlar Üzerinde Kaktüs Bitkisinin Etkisi}

\author{
Eren ERENSAYIN ${ }^{1, a}$, Nurettin TOPALOĞLU ${ }^{1, \mathrm{~b}}$, M. Hanefi CALP*2,c, Serkan SAVAŞ ${ }^{3, \mathrm{~d}}$ \\ ${ }^{l}$ Gazi University, Informatics Institute, Ankara, Turkey \\ ${ }^{2}$ Karadeniz Technical University, Trabzon, Turkey \\ ${ }^{3}$ Ahmet Çiçek Vocational and Technical Anatolian High School, Ankara, Turkey
}

\begin{abstract}
• Geliş tarihi / Received: 10.02 .2018 •Düzeltilerek geliş tarihi / Received in revised form: 07.06.2018 • Kabul tarihi / Accepted: 20.06 .2018
\end{abstract}
\begin{abstract}
People who spend most of their daily lives in environments or labs with computer are exposed to magnetic fields in high levels. In particular, the harmful rays that computer screens transmit are adversely affecting human health. In this study, firstly the negative effects of magnetic fields on human health were examined by literature review. Additionally, whether cactus plants could reduce harmful rays of computer screens were examined and results of measurements done were presented. ELF (very low frequency) measurements were performed by placing the cactus plants and computer screens in various forms and environments. Similar results were obtained with repeated measurements and tests on different (LCD, Tubular) displays, and it was concluded that the cactus plants did not minimize the magnetic field in the environment.
\end{abstract}

Anahtar kelimeler: ELF, Cactus plant, LCD and CRT monitor, Magnetic field

$\ddot{\partial} z$

Günlük hayatın büyük bir bölümünü bilgisayarlı ortamlarda veya laboratuvarlarda geçiren insanlar, yüksek düzeylerde manyetik alana maruz kalmaktadırlar. Özellikle, bilgisayar ekranlarının yaydığı zararlı ışılar, insan săğlı̆̆ını olumsuz etkilemektedir. Bu çalışmada, öncelikle literatür taraması yapılarak manyetik alanların insan sağllğı üzerindeki olumsuz etkileri incelenmiştir. Daha sonra, bilgisayar ekranlarının yaydı̆̆ı zararlı lşılırın kaktüs bitkisi ile minimize edilip edilmediği araştırılmış olup yapılan ölçümlerle sonuçlar ortaya konmuştur. ELF (Çok düşük frekanslı) ölçümleri; kaktüs bitkileri ve bilgisayar ekranları çeşitli şekillerde ve ortamlarda bulundurularak gerçekleştirilmiştir. Sonuç olarak, farkl (LCD, Tüplü) ekranlar üzerinde defalarca yapılan ölçüm ve testler ile yakın değerler elde edilmiş ve kaktüs bitkilerinin ortamda bulunan manyetik alanı minimize etmediği ortaya çıkmıştır.

Keywords: ELF, Kaktüs bitkisi, LCD ve CRT ekran, Manyetik alan

\footnotetext{
*c M. Hanefi CALP; mhcalp@ktu.edu.tr; Tel: (0462) 771 72 50; orcid.org/0000-0001-7991-438X
} 


\section{Introduction}

Scientific research and development studies have produced a modern quality of life on one hand, the pollution that forces quality of life is produced in the same environment on the other hand. By the discovery of electricity in the 19th century, a new dimension of life has been opened and the technological innovations following it have been proliferated (Tatak et al., 2005). While the positive aspect of this knowledge and technological development is to facilitate life, the negative side is that it contains the elements disrupting the quality of life. The use of electric household appliances in daily life is increasing in accordance with the income level of the communities. Any device that operates with electrical current, or cables that carry energy, create electrical, magnetic, or electromagnetic fields around. During the operation of these devices, it is known that the living organisms are affected by the electromagnetic field caused by the devices (Cameron et al., 1993). With the development of technology and the increased use of radiation emitting devices, human body balance constantly exposed to radiation is impaired and various disorders arise. In recent years, with the introduction of computers into daily life, the electromagnetic fields emitted from monitors have been affecting people's health negatively (Arnetz and Berg, 1996). Computer monitors emit electromagnetic radiation at certain frequencies between 0 and $1015 \mathrm{~Hz}$. The electromagnetic energies of the electromagnetic waves in this range are not high enough to break an electron from its orbit. However, as indicated above, these electromagnetic associations have negative biological effects on living organisms (URL-1, 2017).

In this study, it was investigated whether harmful rays of computer screens and radiation were reduced by cactus plants. This is evidenced by the measurements and proved by test results. The study is very important in terms of demonstrating that people who spend most of their daily life in computerized environments or in laboratories must be protected from magnetism. The study was organized in the form of electric and magnetic field in the second part, shape of the electric field perceived in the human body in the third part, effects of computer screens on human health in the fourth part, results of the measurement and evaluation made within the scope of the research in the fifth part, and conclusions and recommendations obtained in the sixth part, respectively.

\section{Electric and Magnetic Field}

Electric field means to the pull or push force effect created by an electric charge on another electric charge. Each electric charge produces an electric field. The presence of electric charges creates the electric field. As the supply voltage of a device increases, the electric field also increases. Electric field strength decreases rapidly as you move away from the source. Electromagnetic fields (EMF) occur when electric and magnetic fields come together. Here, the electric wave and the magnetic wave are displaced together at the speed of light. The distinctive features of electromagnetic fields are the frequencies and wavelengths. "Frequency" is the number of vibrations (oscillations) of a wave in a second and measured by Hertz (Hz). Wavelength is the distance of the waveguide during a vibration. As the frequency increases, the wavelength gets shorter and the energy emitted in the field increases (Karaoglu, 1996).

\subsection{SAR value}

Radio, television and radio systems, radar systems, satellite communication systems, microwave ovens, Global System for Mobile Communications (GSM) communication systems and working systems with Radio Frequency (RF) on medicine and industry are some examples of the systems operating in the $10 \mathrm{kHz}-300 \mathrm{GHz}$ frequency range in the electromagnetic spectrum. The "Specific Absorption Rate (SAR)" is described as the measure of the interaction of the electromagnetic radiation created by such systems with the living tissue. SAR concerns power absorbed in tissues and transforming it into heat (Aral, 2008).

\subsubsection{The importance of SAR value}

"Basic limits" and "derived limits" are defined to determine the limitations that may be detrimental to human health. As a standard basic limit, the value of $4 \mathrm{~W} / \mathrm{kg}$ is considered as the limit value which is defined as "it is harmful if human body temperature increases one degree with absorption of electromagnetic energy". In European countries, the head-zone SAR limit for public is 2 $\mathrm{W} / \mathrm{kg}$ and in the United States is $1.6 \mathrm{~W} / \mathrm{kg}$. On the other hand, the upper SAR limit for arm and leg regions is $4 \mathrm{~W} / \mathrm{kg}$. According to these assumptions, the maximum power value that the tissues can absorb per kilogram is $4 \mathrm{~W} / \mathrm{kg}$. It is defined 10 times lower for workplaces and 50 times lower for public places as security margin 
and the basic limits are $0.4 \mathrm{~W} / \mathrm{kg}$ SAR for workplaces and $0.08 \mathrm{~W} / \mathrm{kg}$ SAR for public places (Aral, 2008).

\subsubsection{Electromagnetic spectrum}

The electromagnetic spectrum is handled differently at different frequencies when the subject is human health. The most important ones are (i) low frequencies and high voltage lines, (ii) mobile communication and GSM networks, and (iii) microwave heating. In the electromagnetic spectrum:

- Preciously low frequency range from $3 \mathrm{~Hz}$ to $3 \mathrm{kHz}$

- Very low frequency range from $3 \mathrm{kHz}$ to 30 $\mathrm{kHz}$

- The region up to $10^{12} \mathrm{~Hz}$ is called radio waves.

- $10^{12} \mathrm{~Hz}$ is the infrared radiation region. All objects radiate at these frequencies.

- Visible light frequencies are $10^{14} \mathrm{~Hz}$. Above these frequencies is the ionizing radiation region, with purple light, $\mathrm{x}$, and gamma rays in this region (Terciyanl1, 2000)

\section{Shape of the Electric Field Perceived in the Human Body}

In the human body, there is the property of conductivity. When the body is exposed to an electric field, the electric charges accumulate on the surface of the body following the induction event. The accumulation of electric charges shows itself in different influences. Micro-sparks are seen between the skin and the object during touch. Vibrations of hair and body feathers manifest itself in a striking way, in the case of static electricity, when the hair is standing on the scalp. These characteristics allow the electric field to be more or less perceived depending on the person. Due to the high amount of body hair, especially when men are more sensitive than women, the sensitivity in animals is higher than both in women and men. Within the same logic framework, the outer part of the hand is 2 to 3 times more sensitive than the palm. When we raise our arms, we increase the electric field at the surface of the arms and hands locally. The perception thresholds of the electric field vary from person to person.

- Below $10 \mathrm{kV} / \mathrm{m}$, very few people feel like "blowing" over their skin,
- Between 10-20 kV/m, some people feel a pinch in their skin,

- From $20 \mathrm{kV} / \mathrm{m}$, more than $5 \%$ of people feel pinning, while others describe it as an unpleasant feeling (Aral, 2008).

It is first necessary to clarify the definitions of radiation and especially ionizing and non-ionizing radiation when it comes to electromagnetic fields and human health. The word radiation is used for the rays that can penetrate into matter. There are two groups according to whether ions penetrate into matter and ionize (electron break) or nonionize.

- Direct Current (DC) to $300 \mathrm{GHz}$ non-ionizing Electromagnetic Radiation,

- Ionizing Nuclear Radiation above $300 \mathrm{GHz}$ (such as neutron, proton, alpha, beta particles, $\mathrm{x}$ and gamma rays) (Karaoglu, 1996).

\subsection{Electromagnetic levels}

The guidelines of the International Non-Ionizing Radiation Protection Board (ICNIRP) refer to limits in two classes. These are; Basic Limitations and Reference Levels.

Basic Limitations: These are electrical, magnetic and electromagnetic fields that directly affect human health and change over time.

Parameters used for basic limitations due to frequency;

- Current density (J) $\left[\mathrm{A} / \mathrm{m}^{2}\right]$

- Specific Absorption Rate (SAR) [W/kg]

- Power density (S) $\left[\mathrm{W} / \mathrm{m}^{2}\right]$

Reference levels: These are measurable quantities for determining whether basic limitations are met. These levels are obtained from computer simulations as well as measurements and tests. Providing reference levels also means that basic limitations are provided. Figure 1 shows the variation of the limit values with frequency. The lower curve shows the general population while the upper curve shows the limit values for the workers. From DC to $1 \mathrm{MHz}$, for example 300 $\mathrm{V} / \mathrm{m}$ is limit for the general public, this value is reduced to $42 \mathrm{v} / \mathrm{m}$ at the $900 \mathrm{MHz}$ frequency reserved for mobile phones (Sevgi, 2005). 


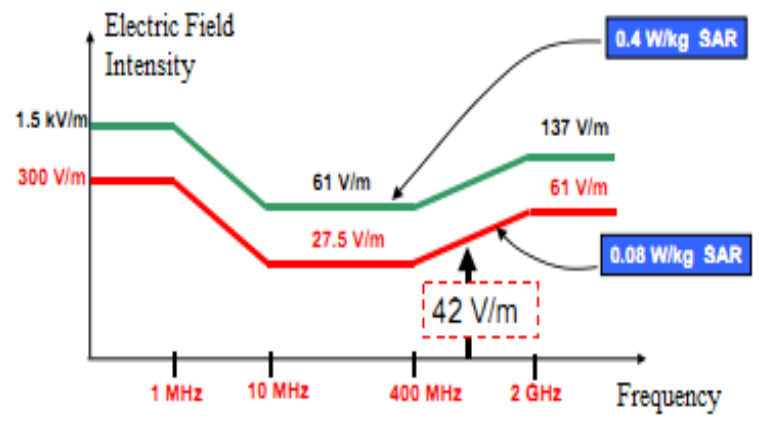

Figure 1. Relationship between current flowing through the body and the time (Sevgi, 2005)
The World Health Organization (WHO) collects studies on carcinogenic substances in four groups; (1) carcinogen, (2) possible carcinogen, (3) likely carcinogen, (4) those not yet classified. Because of the long-term, wide-ranging and reliable studies / researches on high-voltage lines, WHO now relies on research data and shows ELF magnetic fields are now in the possible carcinogen class (Sevgi, 2005). Table 1 provides general public and occupational exposure standards.

Table 1. General public and occupational exposure standards

\begin{tabular}{|c|c|c|c|}
\hline \multicolumn{2}{|c|}{ General Public Standards } & \multicolumn{2}{c|}{ Occupational Exposure Standards } \\
\hline \multirow{2}{*}{$\begin{array}{c}\text { TS ENV 50166-1 } \\
\text { standard }\end{array}$} & E-Field: $10 \mathrm{kV} / \mathrm{m}$ & \multirow{2}{*}{ TS ENV 50166-1 standard } & E-Field: $30 \mathrm{kV} / \mathrm{m}$ \\
\cline { 2 - 2 } & B-Field: $6.4 \mathrm{G}$ & E-Field: $16 \mathrm{G}$ \\
\hline \multirow{2}{*}{ ICNIRP standard } & E-Field: $5 \mathrm{kV} / \mathrm{m}$ & ICNIRP Standard & E-Field: $10 \mathrm{kV} / \mathrm{m}$ \\
\cline { 2 - 2 } & B-Field: $1 \mathrm{G}$ & B-Field: $5 \mathrm{G}$ \\
\hline IARC & ELF magnetic fields have been declared as class 2B carcinogen (October 2001). \\
\hline WHO & For ELF magnetic fields, $3 \mathrm{mG}$ has been reported to increase the risk of leukemia by 1.7 \\
times and 4 mG by 2 times (2004).
\end{tabular}

In Table 2, some devices and their magnetic fields are shown.

Table 2. Some devices and typical magnetic fields (in milligauss) (Sevgi, 2005)

\begin{tabular}{|c|c|c|c|}
\hline Device / Distance (d) & $\mathbf{d = 1 0} \mathbf{~ c m}$ & $\mathbf{d = 3 0 ~} \mathbf{~ m}$ & $\mathbf{d}>\mathbf{1 m}$ \\
\hline Vacuum cleaner & $300-400$ & $30-50$ & $3-5$ \\
\hline Iron & $5-10$ & 1 & 0.5 \\
\hline Washing machine & $20-30$ & $3-5$ & 1 \\
\hline Hair dryer & 400 & 10 & 1 \\
\hline Electric shaver & 200 & 5 & 0.5 \\
\hline Mixer & $70-200$ & $5-10$ & 0.5 \\
\hline Coffee machine & $3-5$ & 0.5 & 0.5 \\
\hline Dishwasher & $20-40$ & $5-10$ & $0.5-1$ \\
\hline Electric oven & $5-10$ & 0.5 & 0.5 \\
\hline Toaster & $5-10$ & 0.5 & 0.5 \\
\hline A refrigerator & $5-10$ & 1 & 0.5 \\
\hline Stereo & $3-5$ & 1 & 0.5 \\
\hline Color TV & $3-5$ & 1 & 0.5 \\
\hline Digital clock & $2-5$ & 1 & 0.5 \\
\hline Air conditioning & 100 & $3-5$ & 0.5 \\
\hline Photocopy machine & $80-150$ & $10-30$ & $1-3$ \\
\hline
\end{tabular}

\section{Effects of Computer Screens on Human Health}

Computers have very important role in people's daily life all over the world (Szeto et al., 2014). In parallel with the increasing popularity of computers, the increase in personal purchasing power has led to the widespread use of computers in both home and business life. The impact of screens on health has begun to be discussed with the widespread use of computers. Much of the research has focused on the level of radiation the screens have been transmitting (Blehm, 2005).

The first damage of the screens to the body is loading of the body with static electricity. In addition, the other harm of the screens is that they tire the brain especially during games because of the color scale they use. Particularly, it is known that children in the $0-6$ age group stay in the 
television or computer for a long time and suffer from consequent eye problems and concentration problems. A normal screen vibrates at a speed of $70 \mathrm{~Hz}$, and the image is refreshed. However, the lower limit for health is $100 \mathrm{~Hz}$. This is the case for TVs as well. At lower speeds, they tear their eyes seriously, such as fluorescent lamps, which tend to deteriorate. It has been observed that electromagnetic waves emitted from monitors reduce the level of melatonin in the body and increase the level of adrenocorticotropic hormone (ACTH) (Arnetz and Berg, 1996). In addition, it has also been reported in experiments that it causes deaths on chicken embryos. It has been stated that electromagnetic fields increase estrogen secretion in women, estrogen can cause breast cancer, and in men stimulate testosterone levels, which can lead to cancer of the prostate or testicle. Computer monitors emit electromagnetic radiation at certain frequencies between 0 (zero) and $1015 \mathrm{~Hz}$. The electromagnetic energies of the electromagnetic waves in this range are not high enough to break an electron from its orbit. However, as noted above, these electromagnetic associations have negative biological effects on living organisms (Karaoglu, 1996; Aral, 2008).

Studies have shown that computer users face with health problems who spend more than 10 years of computer screen face-to-face and at least 30 hours a week. The health problems faced by computer users due to the radiation effects of the screens come from diseases such as bodily discomfort, depression, and obsession. In addition to the mentioned diseases, it is stated that the health problem that most affects the computer users who spend time on the screen is visual symptoms (Blehm, 2005). In a Thomson study, researcher focused on the visual symptoms of computer users and described health problems caused by these symptoms as eyestrain, eye disturbances, eyestrain, strabismus, blurred vision (Portelle et al., 2012). The eye symptoms seen in computer users are generally referred to as "Computer Vision Syndrome (CVS)" and the symptoms increase with the spending time on the computer screen (Büyükbas et al., 2012).

In summary, physical risk factors alleged to originate from screens are usually defined as (URL-2, 2018);

- X-rays emitted from the screen, optical rays, radio frequency rays, very low frequency rays, extremely low frequency rays (Blehm, 2005).

- Ultraviolet and infrared rays,
- VLF, ULF, and ELF electric and magnetic fields,

- Static electric charges,

- Acoustic noise (ultrasonic, infrasound),

- Chemicals emitted from electronic circuit elements to the air Screen flicker,

- Light reflections affecting the eye.

\section{Measurements Carried out Within the Scope of the Research, and its Results}

In this section, the results of the measurement, testing and this analysis reveal whether the cactus plant has reduced the magnetic field.

\subsection{Measuring device}

Devices used in the measurements are taken from Gazi University Faculty of Medicine NonIonizing Radiation Protection (GNRP) Center and are mentioned below.

\section{- Narda EFA 300 Measuring Device}

○ Magnetic (B) Field $(5 \mathrm{~Hz}-32 \mathrm{kHz})$ Probe

- Narda EMR 300 Measuring Device

- Electric Field $(100 \mathrm{kHz}-3 \mathrm{GHz})$ Probes (type 8.3)

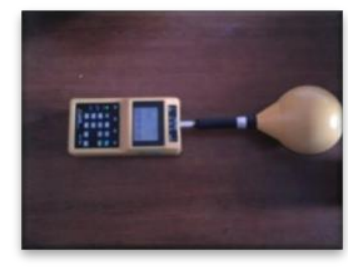

Picture 1. Measuring device

\subsection{Types of cactus used in measurement}

- Acanthocalycium Glaucum

- Agevea Americana Blauw

- Aloe Morlatis

- Armatocereus Cartwrigthtianus

- Pachycereus Pringlei

- Trichocereus Huascha

\subsection{Measuring in front of a tubular display}

ELF measurements were performed by holding cactus all around the tube screen (right, left, back and front). The ELF value in front of the tubular screen was determined by the measurements, and the results were emerged that close to each other in the repeated measurements in front of the screen. The magnetic field in the environment was revealed that the cactuses do not minimize by the tests. For the standard defined by the WHO values 
are $1 \mathrm{mG}$ or less for human health. However, it was observed that the measurements in front of the tubular screen vary depending on the frequency between $1.9 \mathrm{mG}$ and $6.4 \mathrm{mG}$. In Figure 2 , the results from the measurements were shown.

As seen in Figure 2, in the cactus environment, $6.4376 \mathrm{mG}$ was obtained in the measurement in front of the tubular display while similarly, in the cactus-free environment, 6.4378 values have been obtained in front of the screen.

In the measurements made at $60 \mathrm{~cm}$ from the screen, the results obtained in the cactus and cactus free environments were $1,8819 \mathrm{mG}$ and $1,8836 \mathrm{mG}$, respectively, and a very small difference occurred with 0.0017 . This result showed that there was no remarkable effect of the cactus.

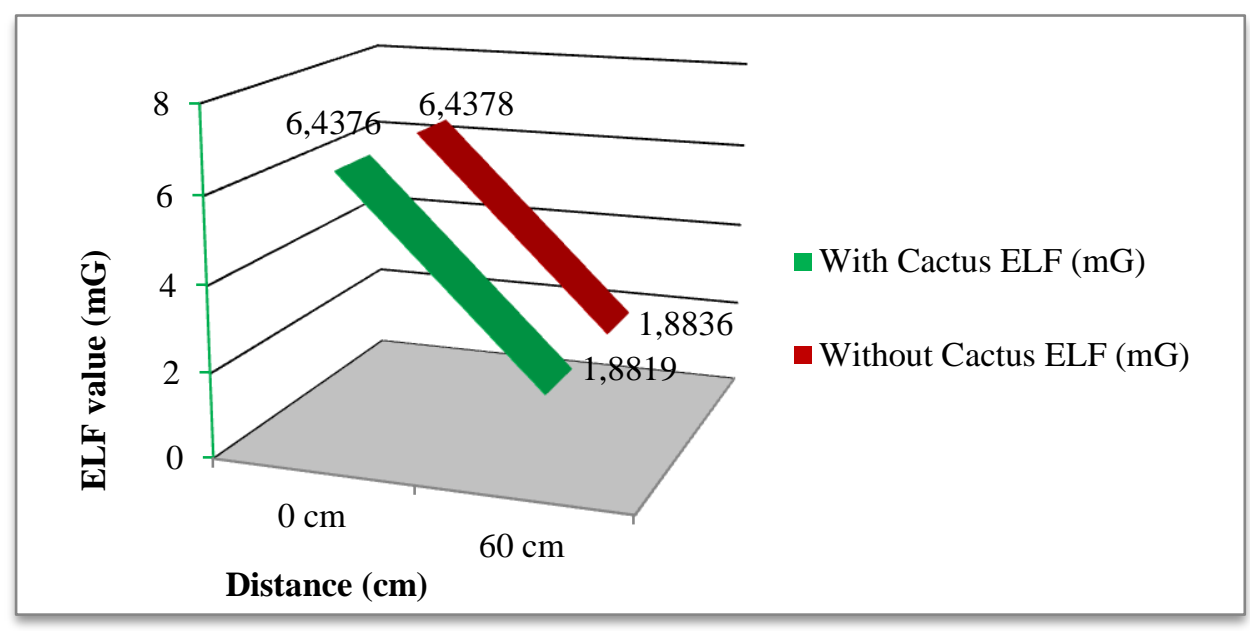

Figure 2. Measurement results in front of the tubular display

\subsection{Measuring done in front of LCD display}

In the study, it was investigated whether or not the cactus plant minimizes the magnetic field that the LCD screens transmit. The measurement results made on the LCD screen were given in figures, pictures and tables. ELF measurements were made with various cacti in various forms and in

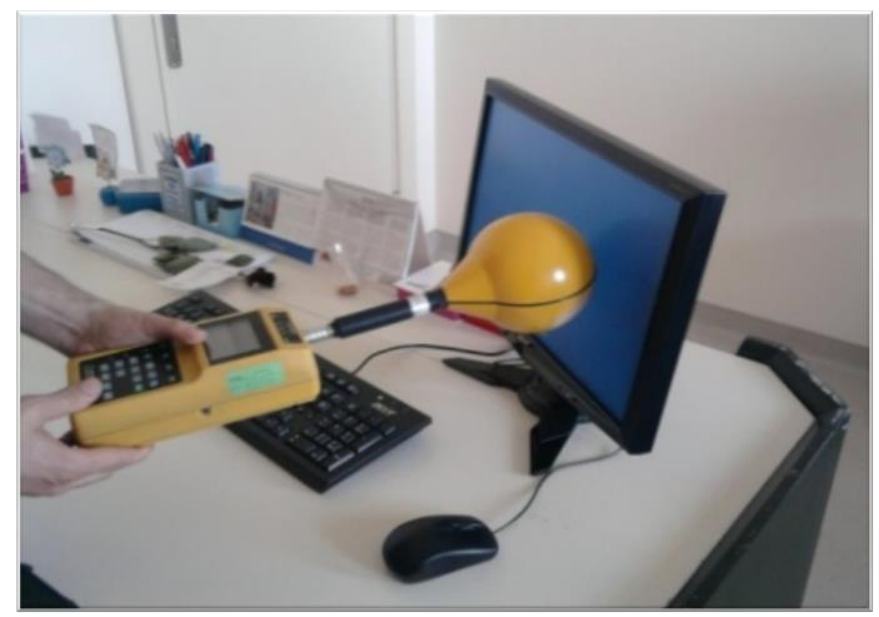

Picture 2. Various Measurements Made with LCD screen

different environments. Similar results were obtained with repeated measurements and tests in front of the LCD displays. The cactuses did not minimize this magnetic field in the environment, and it was emerged by the tests made. In Picture 2 , the measurement environment and, in Figure 2 the data obtained from the measurements were shown. 


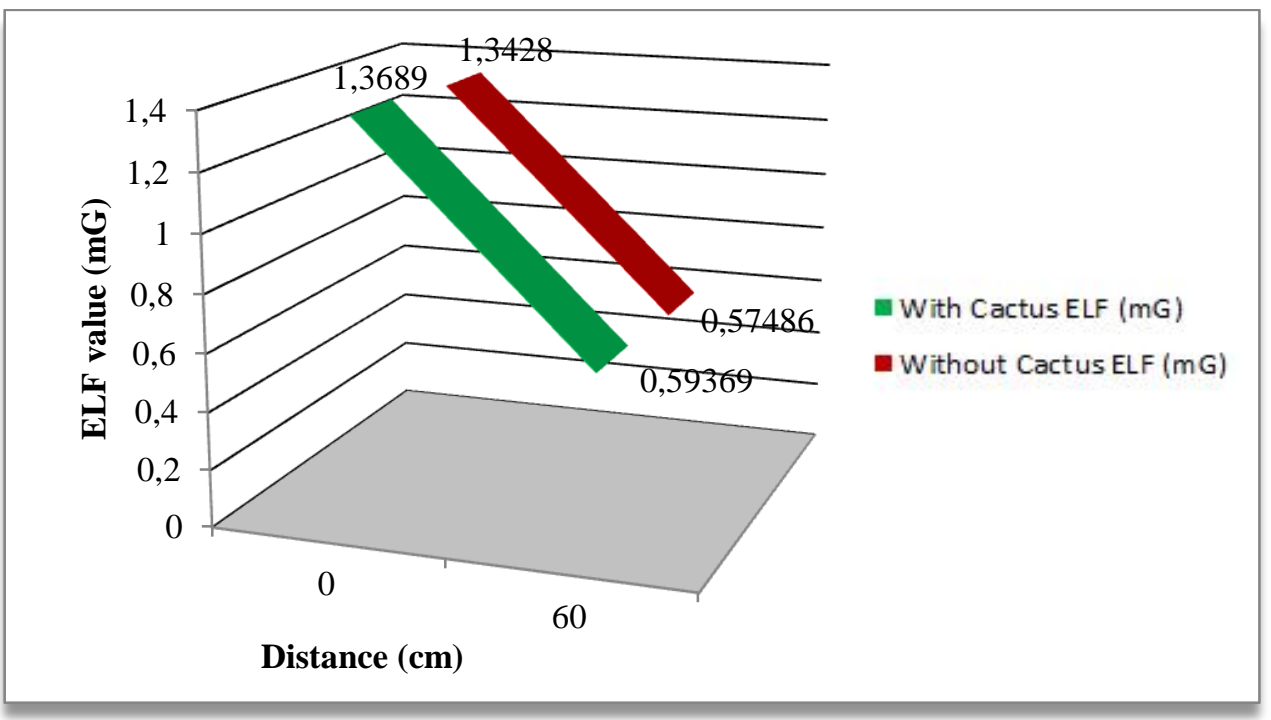

Figure 3. Results of cactus and cactus-free measurements in front of the LCD screen

As seen in Figure 3, in the cactus environment, $1.3689 \mathrm{mG}$ was obtained in the measurement made in front of the screen, while similarly, in the cactus-free environment, 1.3693 was obtained in front of the screen. In the measurements taken at $60 \mathrm{~cm}$ from the screen, the results obtained in the cactus and cactus free environments were respectively $0,5937 \mathrm{mG}$ and $0,6205 \mathrm{mG}$, with a small difference of 0.0268 . This result showed

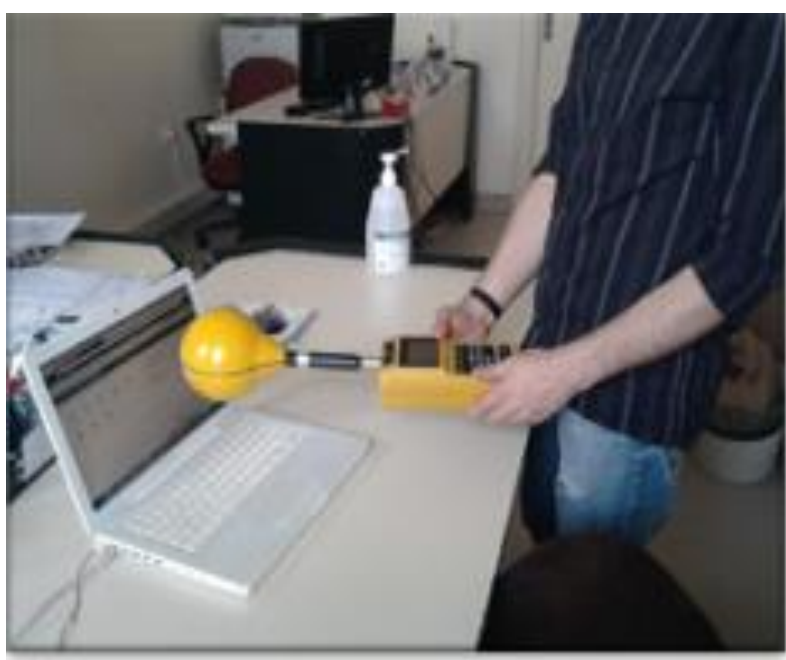

Picture 3. Measuring in front of the MAC screen that there was no remarkable effect of the cactus. In the same way, various measurements were made on different brands and models. As a result of the measurements, it was observed that the cacti had no effect on the magnetic field. The measurements of samples taken from different brands and models were shown in Picture 3-4 and the data obtained were shown in Figure 4-5.

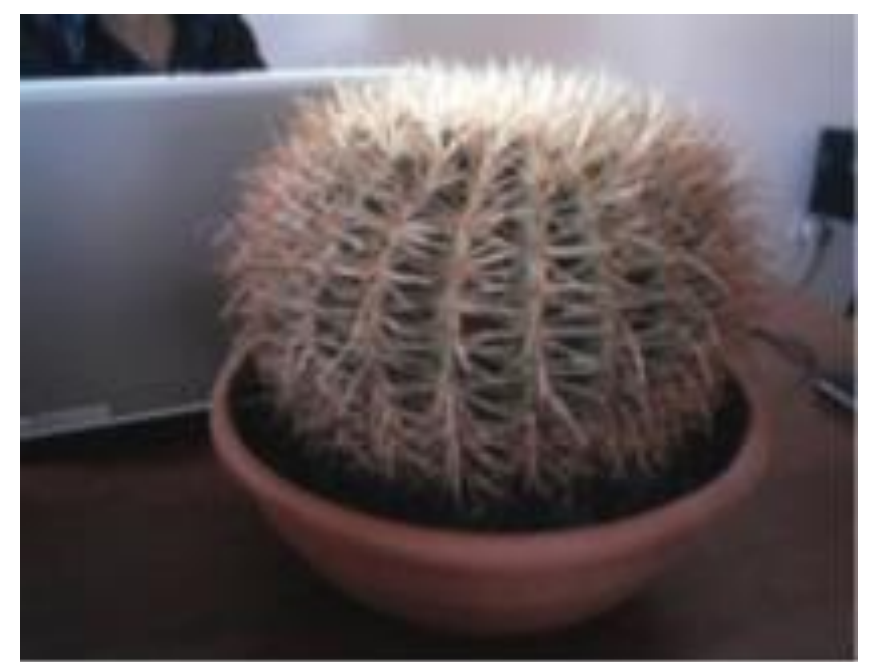

Picture 4. Measuring in front of the laptop screen 


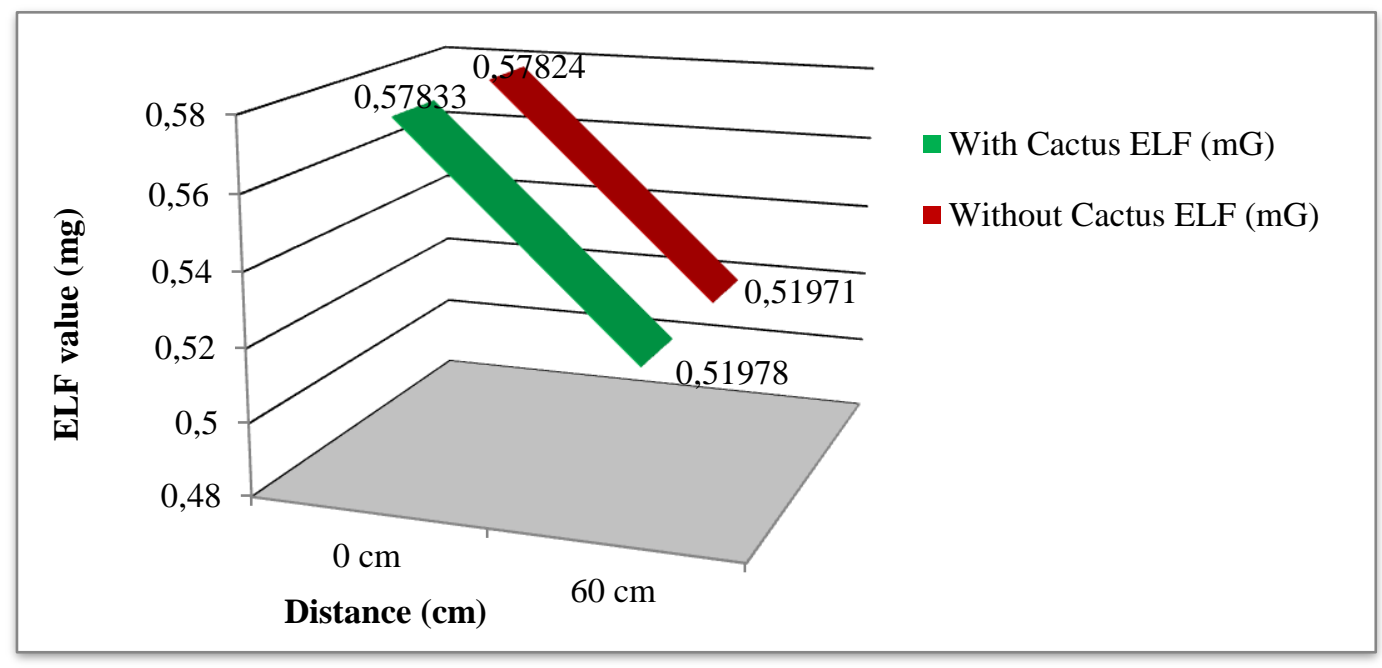

Figure 4. Measurement results in front of the MAC screen

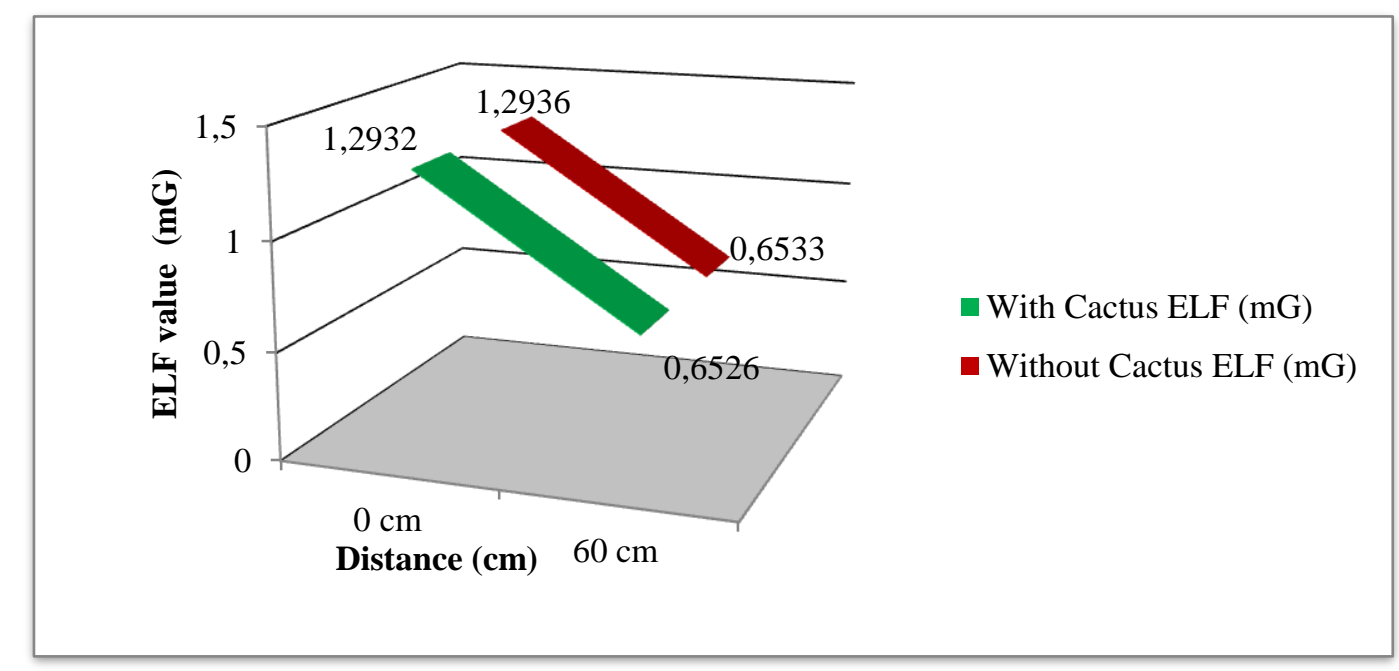

Figure 5. Measurement results in front of the laptop screen

Table 3 also shows how each of the individual ELF value changes depending on the distance.

Table 3. Measurements made in front of various screens in cactus environments

\begin{tabular}{|l|c|c|c|c|}
\hline \multirow{2}{*}{ Product } & \multirow{2}{*}{ Frequency $(\mathbf{H z})$} & \multirow{2}{*}{ Distance $(\mathbf{C m})$} & \multicolumn{2}{c|}{ Measurement Values (Mg) } \\
\cline { 4 - 5 } & & $\begin{array}{c}\text { Cactus } \\
\text { Environment }\end{array}$ & $\begin{array}{c}\text { Cactus-free } \\
\text { Environment }\end{array}$ \\
\hline \multirow{2}{*}{ Tubular Screen } & 92 & 0 & 6.4376 & 6.4378 \\
\cline { 2 - 5 } & 51 & 60 & 1.8819 & 1.8836 \\
\hline \multirow{2}{*}{ LCD Screen } & 52 & 0 & 1.3689 & 1.3693 \\
\cline { 2 - 5 } & 53 & 60 & 0.5937 & 0.6205 \\
\hline \multirow{2}{*}{ Mac Notebook } & 194 & 0 & 0.57833 & 0.57824 \\
\cline { 2 - 5 } & 52 & 60 & 0.51978 & 0.51971 \\
\hline \multirow{2}{*}{ Notebook } & 260 & 0 & 1.2932 & 1.2936 \\
\cline { 2 - 5 } & 50 & 60 & 0.6526 & 0.6533 \\
\hline
\end{tabular}


The most noteworthy feature here for both types of displays (LCD, Tubular) is that the magnetic field is inversely proportional to the square of the distance between the source and the measuring device, and in particular the tube display produces much more electromagnetic field than the LCD screen. Due to these adverse effects on human health, limits have been placed on electromagnetic fields. Measurements were made on computer monitors in line with the standards due to these limitations.

As a result of the measurements, the electromagnetic field values were observed to decrease as they were moved away from the computer monitors. This is also a result of that the computer monitors are inversely proportional to the square of the distance of the electromagnetic fields. Among these standards, the ones outside MPR II and TCO 1999 are applied to the transmitters. MPR II and TCO standards are regulated by the intensity of the electromagnetic field emitted from the monitors. Compared to the standards, the measurements were much higher than the measurements for the standards prescribed for the transmitters. It was found that the standard for monitors is exceeded by the prescribed limits for $30 \mathrm{~cm}$ and for $50 \mathrm{~cm}$ by some computer monitors.

Another important thing to keep in mind is that computer monitors are a source of X-rays, UVA, UVB and UVC. The studies realized in this regard is increasing day by day. The developed byproducts aim to provide the necessary protection in this regard. As a result, users need to work at least 60 to $70 \mathrm{~cm}$ away from computer monitors in order to prevent any damage they may suffer. The Standards published by the Turkish Standards Institute in this regard were generally related to electromagnetic waves emitted from transmitters but not specifically to the electromagnetic fields emitted by computer monitors.

In addition, the following suggestions are important in terms of the human health and should be taken into account in the scope of the study.

Unused screens should be either shut down or removed from plug. The devices will cause electromagnetic pollution as long as they remain in the "Stand by" position. The distance between the computer screen and the keyboard should be $1 \mathrm{~m}$ and the screen filter should be used. User must be at least $2 \mathrm{~m}$ away from the front (and back) of the tubular (CRT) TV screens. If possible, LED, LCD and plasma screens should be preferred. Some users are more sensitive to electromagnetic fields than others. These people may experience extreme sensitivity to computer monitors and other electrical devices, sensation of dryness in the throat, eye problems (pain and visual forimpairment), headache, allergy, redness, insomnia, sensitivity to sounds, difficulty in hearing, fatigue reactions (Seyhan et al., 2018).

\section{Conclusions and Recommendations}

In the study, it was researched with the measurements and tests whether the cactus plant minimized the magnetic fields of the computer screens. All measurements were performed at front and back and on right and left side of screen, and with $60 \mathrm{~cm}$ distance with LCD and tubular display. In the tubular screen measurements, the ELF value has been determined to be high. Also results have been showed that after repeatedly measurements, both screens have reached approximate results. In the same way, various measurements have been made on different brands and models. No effect of the cacti on the magnetic field has been observed in any of the measurements. As a result, the measurements by the cactuses that did not minimize the magnetic field in the computer screens have been revealed and proven by tests.

The study is important for that it draws attention to the damages caused by the magnetic fields created by the computer screens on human health and it reveals if the cactus plants minimized the damages.

\section{References}

Aral, B. S., 2008. "Effect of $900 \mathrm{Mhz}$ and 1800 Mhz Radio Frequency Radiation on Blood Brain Barrier, Gazi University Health Sciences Institute Biophysics Department, Ankara, 76-94.

Arnetz B. B, Berg, M. J., 1996. Melatonin and adrenocorticotropic hormone levels in video display ünit workers during work and leisure. Occup Environ Med. Nov. 38:11 1108-10.

Blehm, C., Vishnu, S., Khattak, A., Mitra, S., Yee, Rr. W., 2005. Computer Vision Syndrome: A Review, Survey of Ophthalmology Volume 50, Number 3, May-June.

Büyükbas Z., Gündüz M. K., Bozkurt B., Zengin N., 2012. Evaluation of ocular surface 
changes seen in computer users, Turkish Journal of Ophthalmology, 42(3): 190-196.

Cameron, I. W., Hardman, W. E., Winters, W. D., Zimmerman, S., Zimmerman, A. M., 1993. Enviromental Magnetic Fields: Influences on Early Embryogenesis, J.Cell. Biochem. 51; 417-425.

Karaoglu, B., 1996. Griftiths Elektromagnetic Theory, Arte Advertisement and Promotion, p.404.

Portelle J. K., Rosenfield, M., Bababekova, Y., Estrada, J. M., Leon, A., 2012. ComputerRelated Visual Symptoms in Office Workers, Ophthalmic \& Physiological Optics, 32, 375-382.

Sevgi, L., 2005. Electricity and Magnetic Fields in the Environment, Dogus University, Department of Electronics and Communication Engineering, Industrial \& Automation, February.

Seyhan, N., Kurşun, A.G.C., Öztürk, G.G., Sırav, B. ve Özgür, E., 2018. Elektromanyetik Radyasyondan Korunmak İçin Pratik Öneriler: Gazi Üniversitesi Tıp Fakültesi Biyofizik Anabilim Dalı, Ankara.
Szeto G.P.Y., Chan C.C.Y., Chan S.K.M., Lai H.Y., Lau E.P.Y., 2014. The Effects Of Using A Single Display Screen Versus Dual Screens On Neck-Shoulder Muscle Activity During Computer Tasks, International Journal Of Industrial Ergonomics, 44, (2014), 460-465.

Tatak, F., Tiryakioglu, İ., Y1lmaz, İ., 2005. Investigation of the effects of electromagnetic waves used in GPS on human health, Map Cadastre Engineers Chamber Engineering Surveys STB Commission, 2nd Engineering Measurements Symposium (23 -25 November 2005 İTÜ-İstanbul), 641-648.

Terciyanl1, A., 2000. Electromagnetic Pollution and GSM, Biltek, Decebmer 2000, TÜZÜNER S.2002. ÇED, www.teas.gov.tr.

URL-1, 2017. TMMOB Chamber of Electrical Engineers, www.emo.org.tr/ekler/d7f9017fbda6919_ek .doc?tipi $=46 \&$ turu $=\mathrm{X}, \quad$ Access Date: November 2017.

URL-2, 2018. Artun, T., http://www.sibernet.com.tr/dr.htm, Access Date: January 2018. 